\title{
Investigation and analysis of groundwater-derived damage to the Shahe ancient bridge site in Xi'an, China
}

\author{
Jing Cao ${ }^{1}$, Bingjie Mai ${ }^{1}$, Hua Chen ${ }^{2 \dagger}$, Yuhu $\mathrm{Li}^{1 \dagger}$ and Juanli Wang ${ }^{1{ }^{* \dagger}}$
}

\begin{abstract}
Earthen cultural ruins and their subsurface environments act as carriers or support for aboveground cultural heritage artefacts, and groundwater has been identified as the most important factor accelerating the destruction of ruins. In this paper, a wooden structure on the site of the Xianyang Shahe ancient bridge is taken as the research object. Through geotechnical surveys and site sample analyses, the relationship between the environment and cause of damage at the site is explored. Fluctuations in ground water level are found to affect the movement of water and salt, thereby accelerating deterioration and allowing microbes and other soil inhabitants and plants to erode the ruins. Furthermore, strong correlations are revealed between the stratigraphy of the area and both ruin status and sample analysis results. Geotechnical investigation data are used to predict the effects of various damaging factors on longterm preservation and the underlying mechanisms and to propose feasible, long-term countermeasures for preservation studies.
\end{abstract}

Keywords: Geotechnical investigation, Groundwater, Damage analysis, Earthen cultural ruins

\section{Introduction}

Cultural heritage is defined as a set of large settlements, city sites, palaces, tombs, and other sites of great scale, value, cultural and artistic significance with a far-reaching influence which they have a wide spatial distribution, many types of ruins existing on various large scales, and they are usually subjected to natural and anthropogenic factors $[1,2]$. In terms of cultural monuments, earthen ruins and their subsurface environments act either as a carrier of or a support for aboveground cultural heritage artefacts. The aboveground part of a site and its subterranean environment were an inseparable whole. Moreover, the differences in the types and materials of the sites

\footnotetext{
*Correspondence: wangjuanli@snnu.edu.cn

tHua Chen, Yuhu Li and Juanli Wang have contributed equally to this work

${ }^{1}$ Engineering Research Center of Historical and Cultural Heritage Protection, Ministry of Education, Shaanxi Normal University

Xi'an 710069, Shaanxi, China

Full list of author information is available at the end of the article
}

themselves as well as their variable and complex geological, hydrological and environmental relationships make the analysis of the causes of damage and the identification of countermeasures to preserve such sites extremely difficult.

Standards and methods for the protection of large sites have improved. The maintenance of such sites involves many disciplines [3], such as architecture, archaeology, geology, physics, and biology, and requires a root cause diagnosis and identification of the destruction mechanism [4-7]. More importantly, how to mitigate further destruction with minimal intervention needs to be determined, and a set of scientific diagnoses, treatments, and effective management for the protection of large sites needs to be established. Prior to the most recent decade, cultural heritage preservation studies incorporated a more multidisciplinary and holistic approach, and more attention was given to the broader subsurface environmental conditions of a site [8-16]. Accordingly, innovative and reliable approaches have been developed for the

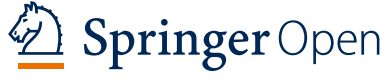

(c) The Author(s) 2021. Open Access This article is licensed under a Creative Commons Attribution 4.0 International License, which permits use, sharing, adaptation, distribution and reproduction in any medium or format, as long as you give appropriate credit to the original author(s) and the source, provide a link to the Creative Commons licence, and indicate if changes were made. The images or other third party material in this article are included in the article's Creative Commons licence, unless indicated otherwise in a credit line to the material. If material is not included in the article's Creative Commons licence and your intended use is not permitted by statutory regulation or exceeds the permitted use, you will need to obtain permission directly from the copyright holder. To view a copy of this licence, visit http://creativecommons.org/licenses/by/4.0/. The Creative Commons Public Domain Dedication waiver (http://creativeco mmons.org/publicdomain/zero/1.0/) applies to the data made available in this article, unless otherwise stated in a credit line to the data. 
damage analysis of cultural ruins because multidisciplinary collaboration contributes to a better understanding of the preservation conditions and deterioration degree of ruins [13], the effects of various types of perturbations, and the mechanisms by which perturbations accelerate deterioration. Through geotechnical surveys and ruin sample analyses, this paper reveals the relationship between the environment and cause of damage at the site, and countermeasures for long-term preservation are proposed.

There have been few studies on wooden structure sites, those mainly focus on several aspects of disease diagnosis and preservation status evaluation $[17,18]$, and the protection of such sites is mostly based on classification and protection through the identification of soil types and cultural relics present in the studied sites. Generally, study site soil types are mainly reinforced to prevent further weathering, while studies on the remains of wooden cultural relics mainly focus on anti-corrosion and reinforcement measures, which include research on the suitability of preservation environments. Studies on the integrity of wooden structure sites have been divided into two research objects, earthen sites and wooden cultural relics, thereby ignoring the closely connected and indivisible interdependence of the two. There is still a certain degree of uncertainty regarding the protection of wooden structure sites, and there is a lack of universal and systematic protection methods.

Among the numerous factors that accelerate the destruction of sites with wooden structures, groundwater [19] has the greatest impact. Fluctuations in groundwater level affect the movement of water and salt, which influence the deterioration of earthen ruins and associated aboveground structures and cause considerable damage to both the aboveground and subterranean components of wooden structures. Protocols for damage assessment aimed at cultural heritage preservation, particularly for ruins affected by groundwater damage, have still not been standardized. This paper takes the Xianyang Shahe ancient wooden bridge site as the research object. Through geotechnical surveys and sample analyses, the relationship between the environment and cause of damage is explored, the effects of various damaging factors on long-term preservation and the associated mechanisms are predicted, and feasible, long-term countermeasures for preservation studies are proposed.

\section{General description of the Shahe ancient bridge}

The Xianyang Shahe ancient bridge [20] located in the Shahe Ancient River channel, $10 \mathrm{~km}$ southwest of the city of Xianyang, Shaanxi Province (as shown in Fig. 1). The Shaanxi Provincial Archaeological Institute excavated it in 1986 and cleaned two bridge sites. Bridge

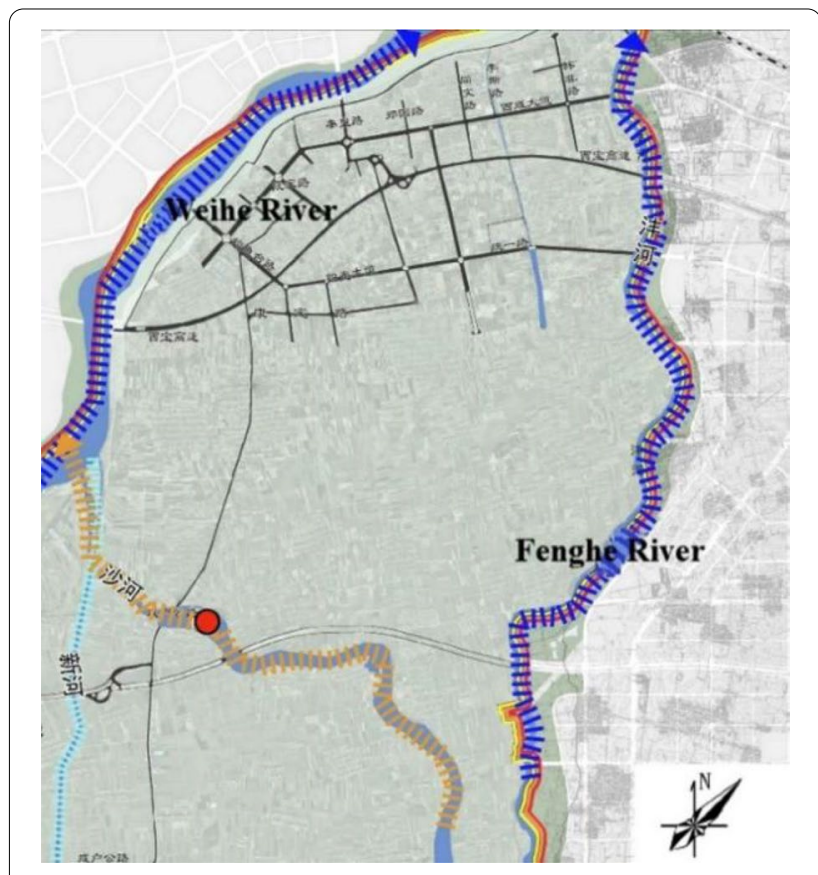

Fig. 1 Location map showing the ruins

No. 1 was neatly arranged into piles, and 16 rows of 143 bridge piles were cleared; bridge site No. 2 was cleared of 5 rows of 40 bridge piles in an east-west arrangement with a north-south correspondence. The bridges width was approximately $16 \mathrm{~m}$. According to expert opinion, from a geographical point of view, this bridge was the first bridge leading out of the city of Chang'an built in the west. It connected the cities of Qin Xianyang and Han Chang'an to the Shanglin Garden; it was located west of Bashu and was used to cross the Feng River. It is the oldest wooden bridge site discovered in China so far. In 1989 , it was rated one of the top ten archaeological discoveries in the country. It was designated as a key cultural relic protection unit in Shaanxi Province in 1992, also identified as part of the seventh national key cultural relic protection unit batch by the State Council in 2013. The bridge is referred to as the "Desert Silk Road" as it connected the northwest and the "Southwest Silk Road", thereby connecting the southwest region; it is also referred to as the "First Bridge of the Silk Road" and has important academic value in archaeological studies of the Silk Road. Additionally, ancient wooden bridges with such a time span and spatial scale are rare. It provides valuable information and evidence for archaeological and academic studies on the history of transportation and bridges in China. It represents the true preservation of ancient bridge construction technologies and large-scale transportation construction techniques in the territory at that time. 
Site No. 1 of the Xianyang Shahe ancient bridge was excavated and had a length of $106 \mathrm{~m}$ and a width of $16 \mathrm{~m}$, and a temporary protection shed was built on the site. The bridge piles were constructed using 16 rows of 112 logs, with each row having a spacing of 3 to $5 \mathrm{~m}$ (as shown in Fig. 2). According to the C14 measurements, the site was built during the Qin Dynasty 2120 years ago. Particularly the Xianyang Shahe ancient bridge ruins described in this article, the wooden bridge piles on the leakage part of the surface of the ruins are important cultural relics that was constitute an integral part of the overall bridge structure, the preservation status is concerning, as revealed by the excavation of the site No. 1 pit bridge pile, the wooden pile body exhibits various degrees of decay, cracking, surface pollution, mould, crooked flash, breakage and other forms of disease progression, which have seriously affected its display and longterm preservation ability. The degree of disease is still advancing every year, and the site displays an urgent need for protection and restoration.

\section{Meteorology and hydrology}

The area where the Shahe ancient bridge site is located belongs to a warm temperate semi-humid continental monsoon climate area with distinct cold, warm, dry and wet seasons; thus, this area is rich in light, heat and water resources. The area belongs to the Weihe River system of the Yellow River Basin and is located within the hydrogeological area that encompasses the river terrace. The Weihe River is the largest surface water system in the area. It flows from west to the east along the southern edge of the municipal area. The water volume changes seasonally, with an average flow of $173 \mathrm{~m}^{3} / \mathrm{s}$. The riverbed is wide and shallow, with a water depth of $3.0 \mathrm{~m}$ during the flat-water period, during which the riverbed ratio drops by approximately $1 \%$. The Feng River is a first-order tributary that flows into the Weihe River from south to north. The riverbed width is $80-250 \mathrm{~m}$, and the average flow rate is $9.41 \mathrm{~m}^{3} / \mathrm{s}$; the riverbed ratio drops by approximately $8.2 \%$ during the flat-water period.

The groundwater at the study site is mainly quaternary loose layer pore diving water and confined water.

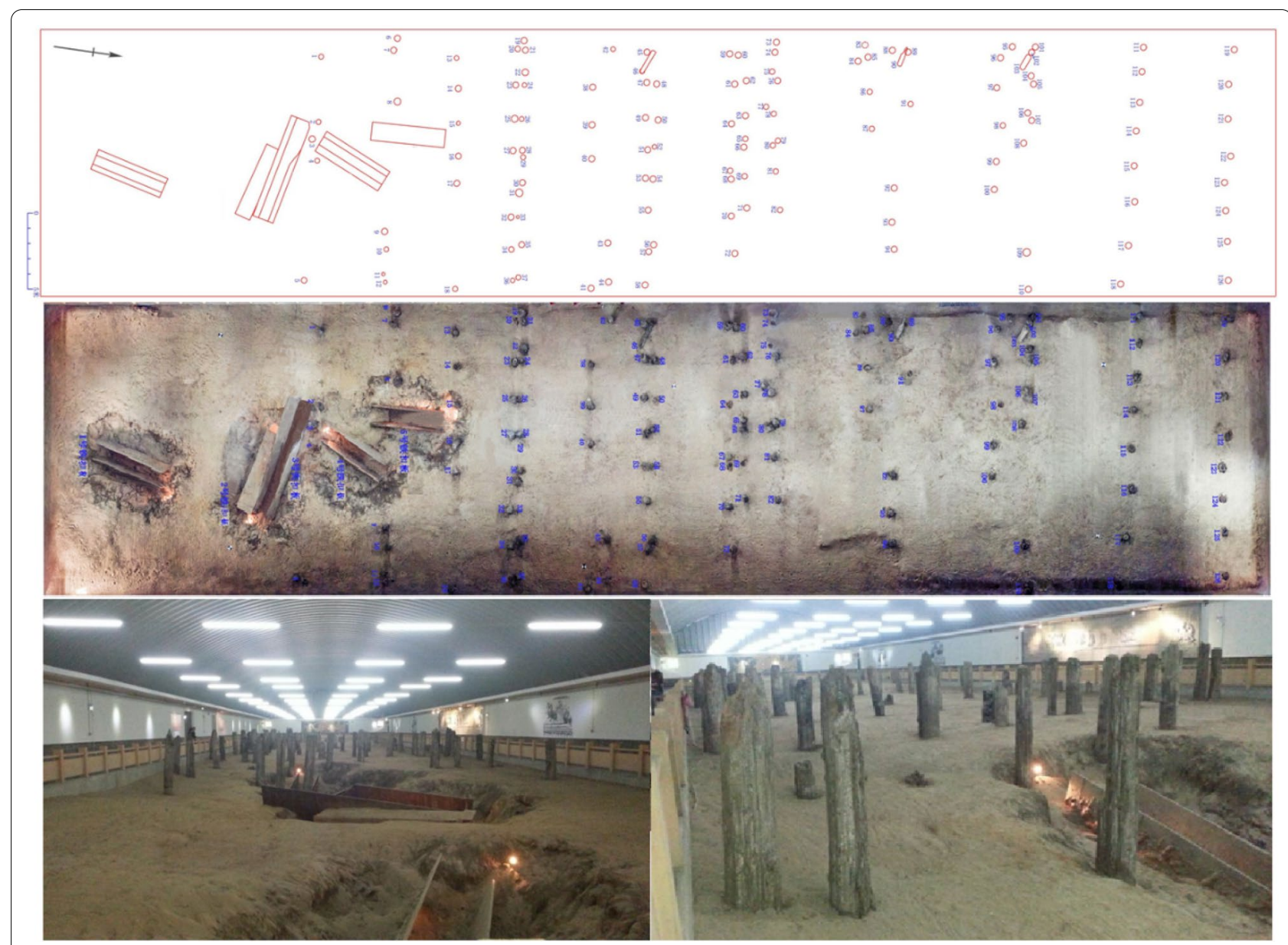

Fig. 2 View of the ruins 
The diving water is mainly found in the Quaternary Upper Pleistocene and Middle Pleistocene alluvial sandy soil, and it is mainly supplied by atmospheric precipitation, infiltration, irrigation and lateral runoff. The runoff direction is consistent with the terrain slope, flowing from southeast to northwest, and the vertical quaternary loose layer pore water and shallow confined water are connected and supplied through overflow. The drainage methods are mainly evaporation, lateral runoff drainage, artificial mining, and overflow diving drainage. The unit water inflow is $5-10 \mathrm{~m}^{3} / \mathrm{h} * \mathrm{~m}$, and the aquifer thickness is $34-46 \mathrm{~m}$. It is recharged by runoff from upstream rivers and the confined aquifer of the Loess Plateau; the confined aquifer consists of lacustrine sediments, and the lithology mainly consists of medium coarse sand and gravel. The thickness of the aquifer is $27-80 \mathrm{~m}$, and the unit water inflow is $1-10 \mathrm{~m}^{3} / \mathrm{h} * \mathrm{~m}$. The salinity level is less than $230 \mathrm{mg} / \mathrm{L}$, making it a fresh water source. The terrace where the site survey area is located belongs to a strong water-rich area, and the water inflow is $<2500$ $5000 \mathrm{~m}^{3} / \mathrm{d}$.

During the survey of the Meteorology and Hydrology, it was found that the natural precipitation in the site area varies greatly between years, and the seasonal distribution is uneven; the groundwater level is closely related to season, climate, groundwater storage, recharge and discharge. In summer, there is abundant precipitation, and the water level rises significantly; in winter, the amount of precipitation decreases, and the groundwater level drops accordingly. The underground diving level has an elevation of $343.00-344.40 \mathrm{~m}$ and a water level of $5.20-5.80 \mathrm{~m}$.

\section{Experimental methods}

The investigation process of the wooden structure site is shown in Fig. 3, after collecting and analysing preliminary and regional data, combined with the characteristics of bridge site No. 1 of the Xianyang Shahe ancient bridge, this study mainly utilized drilling methods, comprehensive engineering geological mapping-based methods, in situ testing techniques, sample collection and indoor test surveys combined with the exploration testing methods. The purpose was to investigate and study the topography, stratum lithology, geological structure, groundwater, and undesirable geological phenomena of the site and performed to evaluate the site's geological conditions [21, 22]. In addition, through the site survey, data analysis and sample testing, diagnosis, and analyse the various causes of disease progression and the conditions or factors that prompt it to continue to develop. The purpose was to find a way to correlate the environment in which they exist to the causes of such diseases.

\section{Drilling and shaft prospecting method}

These points sampling and testing methods were based on the principle of minimum intervention. We collected soil samples and drilled in situ test exploration holes along the Shahe ancient bridge site within at least $1 / 2$ of the total number of exploration holes and sample holes at least $1 / 3$ and arrange a certain number of controlled holes

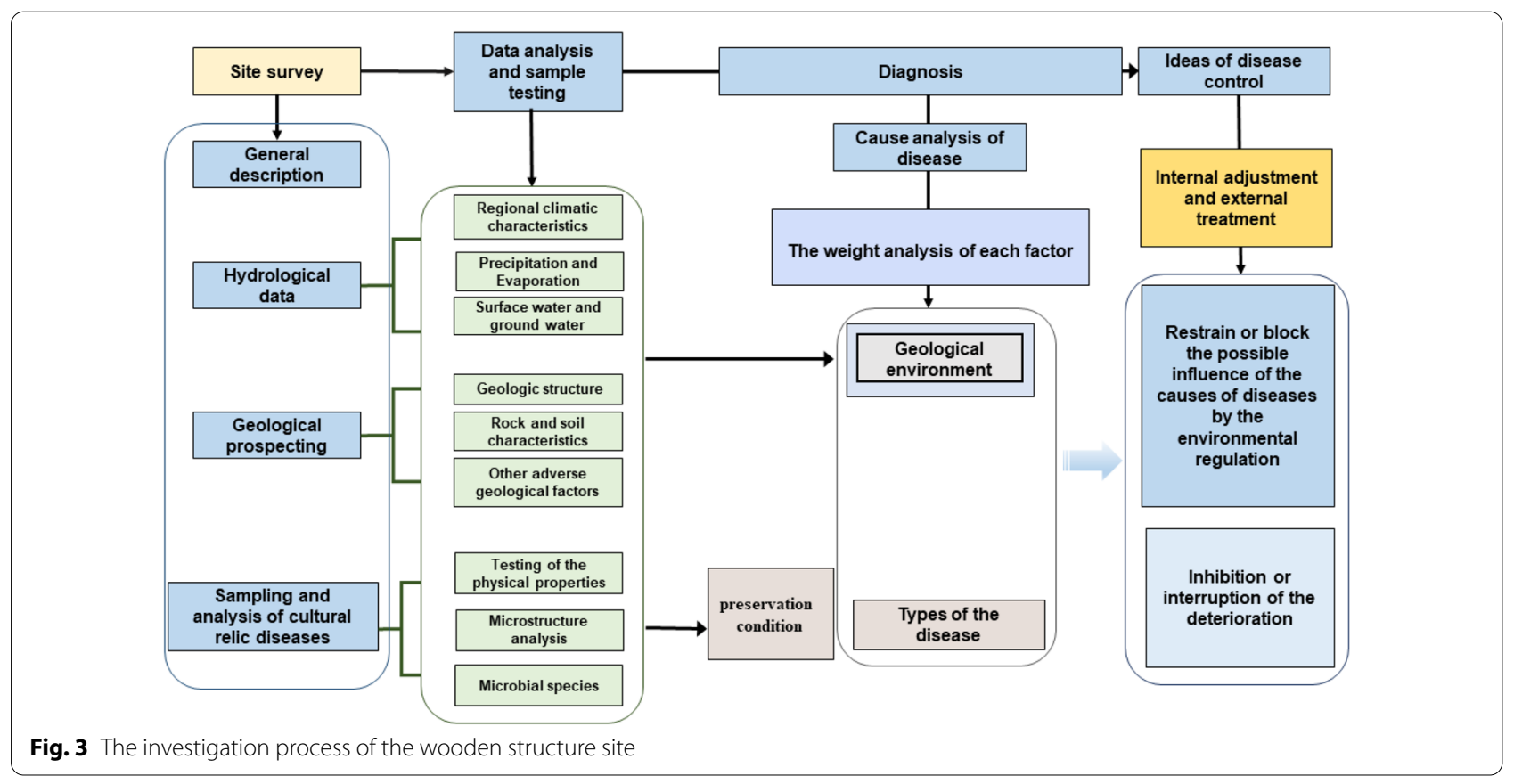


(Fig. 4). According to the above principles [23], 8 exploration points ( 8 drill holes) were arranged in a grid according to the perimeter and corner points of the greenhouse, with a spacing of $24.57-34.73 \mathrm{~m}$; depth of the exploration points was 15-20.5 m. The number of effective mechanical parameters with a satisfactory coefficient of variation within the main engineering geological layer within the survey depth was above 8 ; to survey and measure the exploration points, GPS surveying was adopted and controlled according to the control points on the topographic map of the greenhouse area. After exploration, the coordinates and elevations of all exploration points were remeasured. The coordinate system used was the National Geodetic 2000 coordinate system, which has a $108^{\circ}$ central meridian. The control points used for measurement were as follows:

GPS01 : $X=3792502.4870, Y=562856.18, Z=349.245$

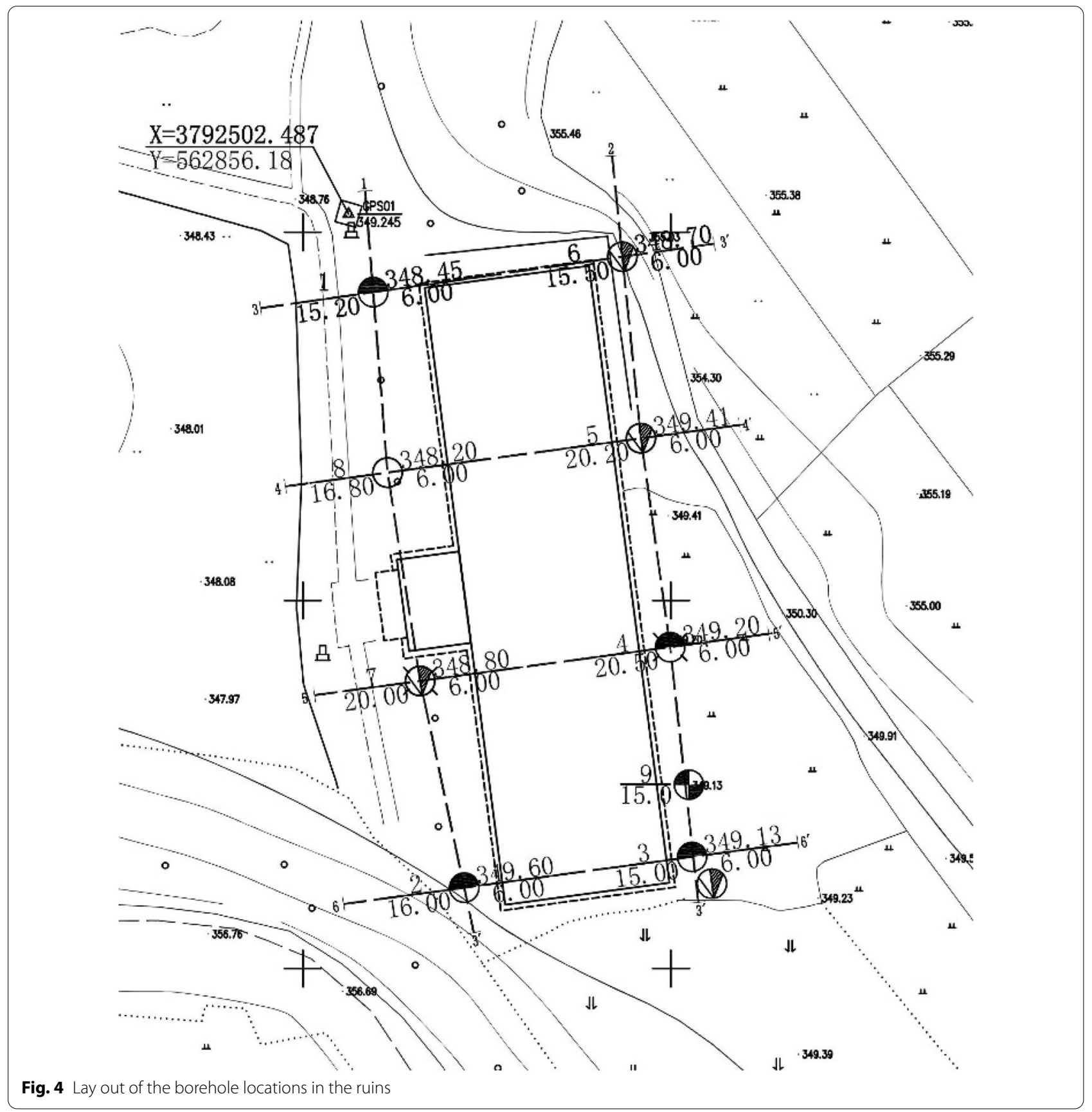


GPS02: $\mathrm{X}=3792528.3774, \mathrm{Y}=562761.8212, \mathrm{Z}=348.0910$

In this survey, a 1:100 scale was used to conduct a detailed investigation of the area and its surroundings, stratum, geological structures, and unfavourable geological conditions affecting the Shahe ancient bridge site.

\section{Sampling and testing methods}

The sampling and testing methods were based on the principle of minimum intervention. A mud wall was used for drilling below the sampled water level, and a thinwalled earth borrower was used to supply static pressure over the water level. The original sample below the water level was taken from the drilling tool, and as the quality class was of class I-II, in situ standard penetration and heavy-duty dynamic penetration testing could be completed on site in addition to routine testing of the soil samples, which included the collapsibility test, selfweight collapsibility test, compression test, penetration test, soil and water corrosion analysis, and rock compressive strength analysis test. The parameter values of c, $\phi$, $\mathrm{q}_{\mathrm{c}}, \mathrm{f}_{\mathrm{s}}, \mathrm{V}_{\mathrm{s}}, \mathrm{V}_{\mathrm{p}}$ mentioned in "Geotechnical and mechanical parameter statistics and values" are carried out in accordance with the provisions of "Code for Geotechnical Engineering Investigation" GB50021-2001, "Technical Code for Geotechnical Engineering Investigation" (YS52022004) and "Standard for Geotechnical Test Method" (GB/ T50123-2019).

\section{Geotechnical and mechanical parameter statistics and values}

The physical and mechanical properties of each layer were counted according to the characteristics of the rock and soil layer, and obvious discrete data caused by unevenness or the interlayer were removed (Additional file 1). The recommended values of the general physical and mechanical parameters of the soil were expressed as statistical average values, in which the shear strength indicators (c, $\phi$ values) were based on the standard values obtained from statistical evaluation, and the cone tip resistance $\mathrm{q}_{\mathrm{c}}$, side friction resistance $\mathrm{f}_{\mathrm{s}}$, shear wave velocity $\mathrm{V}_{\mathrm{s}}$, compression wave velocity $\mathrm{V}_{\mathrm{p}}$ and other in situ test parameters produced the recommended values based on the statistical average value of the test results. For the geotechnical parameters, such as the bearing capacity characteristic $d$, the standard value of the ultimate frictional resistance $\mathrm{q}_{\text {sik }}$ of the surrounding soil of the bored pile and the standard value of the ultimate resistance $\mathrm{q}_{\mathrm{pk}}$ were determined; various methods were combined to determine the recommended value.

\section{Identification of wood species}

As the wood samples collected at the site of the ruins all showed various degrees of decay, it was necessary to saw after reinforcement treatment to obtain three-section standard cuboid samples (cross section, diameter section and chord section) by softening and cutting the bulk samples to attain observation sections. We were therefore able to observe the structural characteristics of the wood using an optical microscope; we then referred to the wood database Inside Wood, "Chinese Wood History," and wood atlas to identify the species of the wood samples [24, 25].

\section{Microbiological testing}

At each site, left and right samples were collected from one randomly sampled sample, and three biological replicates were made for the left or right sites for subsequent sequencing of the amplicons [26-28]. All sampled tissues were put into sterilized plastic bags. The regular hexadecyltrimethylammonium bromide (CTAB) method was used to extract the total DNA contents from the soil and bricks. The concentrations and purities of the isolated DNA were measured using a Nano Drop ND-1000 spectrophotometer (Thermo Fisher Scientific, USA). A pair of primers, ITS3F (GCATCGATGAAGAACGCAGC) and ITS4R (TCCTCCGCTTATTGATATGC), were used to amplify the fungal ITS2 rDNA region. Another pair of primers, 338F (ACTCCTACGGGAGGCAGCA) and 806R (GGACTACHVGGGTWTCTAAT), was applied to amplify the V3-V4 region of bacterial $16 \mathrm{~S}$ rDNA. The PCR products were purified and sequenced using the Illumina HiSeq. platform from Beijing Biomarker Biotechnology Co. LTD. (Hiseq 2500 PE250). All sequence data were deposited under the PRJNA604508 ID in the Sequence Read Archive (SRA) of the NCBI Database.

\section{Microstructure characterization}

Scanning electron microscopy was performed with a Hyperdepth three-dimensional video microscope to observe the microscopic morphologies and fibre structure characteristics of the wood samples and obtain the characteristic performance indexes of the wood corresponding to the different sampling sites at various burial depths.

\section{Results and discussion}

Through the investigation of the topography, geological structure, groundwater and surface water, and unfavourable geological phenomena at the site, it was found that groundwater level fluctuations affect the movement of water and salt, thereby influencing and accelerating the deterioration and causing microbes, creatures, and plants 
to erode the ruins [29-32]. The stratigraphy revealed a good correlation with the status of the ruins, the analysed sample properties, and the damage mechanisms.

\section{Geotechnical characteristics}

The strata within the depth of exploration are described in detail as follows:

Following the geological stratigraphy observed in the borehole, Fig. 5 shows that the stratum where the site is located is mainly composed of Quaternary alluvial fine sand, coarse sand, gravel sand, boulder and silty clay.

(1) Pleistocene Q3 on the fourth system.

(1) The $\mathrm{Q}_{3}{ }^{\text {al }}$ fine sand layer has a layer thickness of $1.0-4.0 \mathrm{~m}$, a burial depth of $1.0-7.0 \mathrm{~m}$, and a bottom elevation of $342.20-348.60 \mathrm{~m}$. (2) The $\mathrm{Q}_{3}{ }^{\mathrm{al}}$ medium sand layer has a layer thickness of 4.00-9.60 m, a burial depth of 7.20-18.1 m, and a layer bottom elevation of 331.20$341.50 \mathrm{~m}$. (3) The $\mathrm{Q}_{3}{ }^{\text {al }}$ gravel layer has a layer thickness of $2.00-3.10 \mathrm{~m}$, a burial depth of $10.30-12.20 \mathrm{~m}$, and a layer bottom elevation of $336.60-338.40 \mathrm{~m}$. (4) The $\mathrm{Q}_{3}{ }^{\mathrm{al}}$ boulder layer has a layer thickness of $2.00-7.80 \mathrm{~m}$, a burial depth of $14.00-20.00 \mathrm{~m}$, and a layer bottom elevation of $328.80-335.60 \mathrm{~m}$. The overall distribution of the stratum is stable, the sedimentation rhythm is clear, the uniformity of the foundation soil of each layer is good, the bearing capacity gradually increases from top to bottom, and the geotechnical engineering properties gradually improve from shallower to deeper layers. The compressibility of the formation is relatively good, and the strength is relatively high. The whole field is basically a stable-stable foundation. The foundation soil of the shallow foundation mainly consists of a Quaternary Upper Pleistocene alluvial layer (1) of fine sand and a (2) middle layer sand.

\section{Permeability}

In this investigation, conventional physical and mechanical property tests were conducted on the loess-like soils, ancient soil layers, silty clay components and other soil samples. The layered statistics of the physical and mechanical properties of each soil layer was calculated.

A standard penetration test (Table 1) was conducted to evaluate the permeability of each layer of sandy soil and cohesive soil distributed in the site, the statistical results of the laboratory penetration test and particle analysis are shown in the Table 2. It indicted that the layer (1) shows the medium permeable, the surface fine sand may have upper stagnant water, which will have a certain influence on the stability of excavation. When local stagnant water is found during excavation, pumping and draining should be carried out in time to ensure the stability of the pit wall. In addition, it also indicates that the evaporation rate will be affected by the surface fine sand layer and the capillary lifting of groundwater in this region will

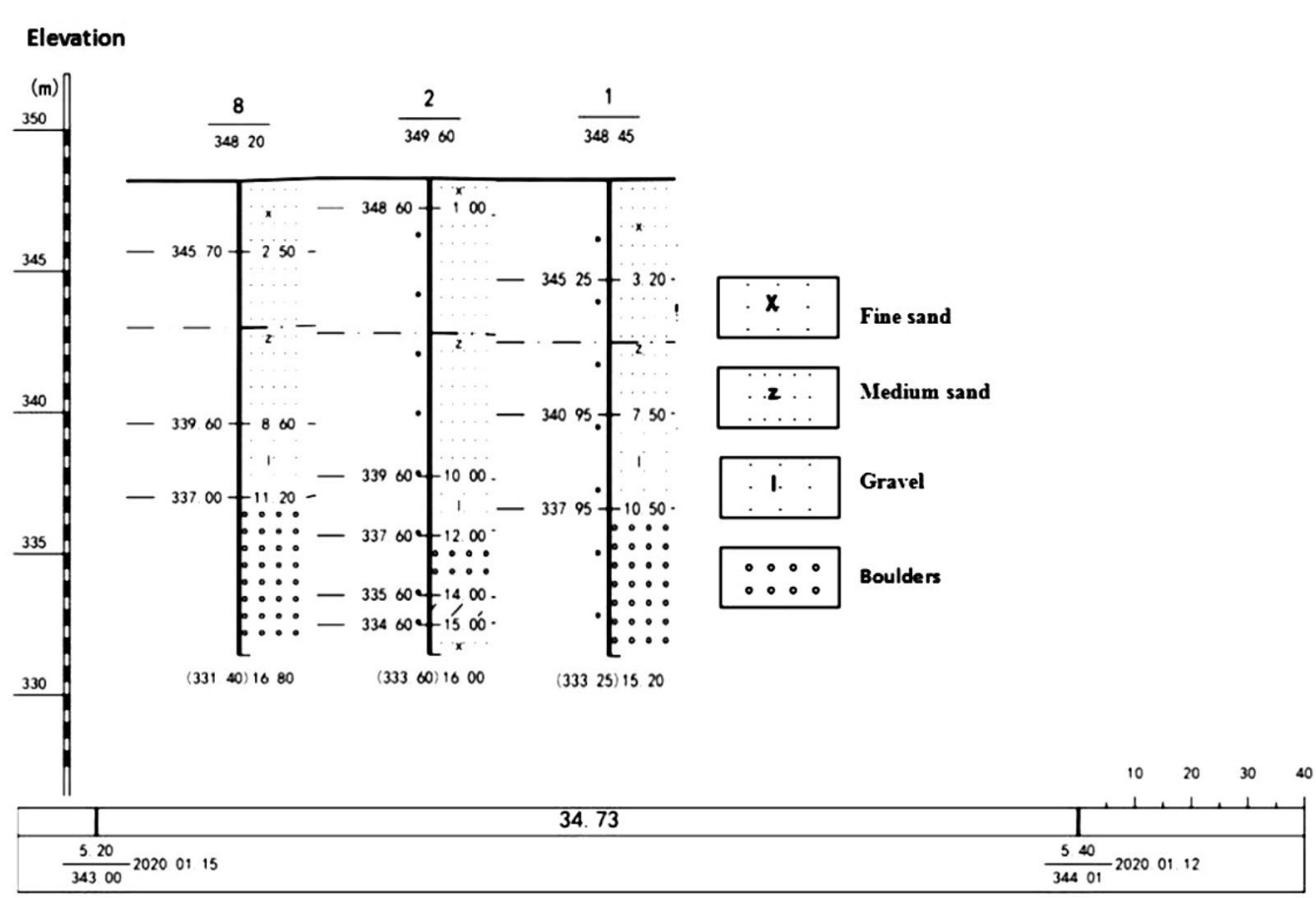

Fig. 5 Simplified geological stratigraphy observed in the borehole. (1, 2, and 8) 
be affected and resulted in the water retention between this region and the strong permeable layer at the bottom layer, so that the water content in this region presents a large accumulation, and the soluble salt also accumulates here.

\section{Environmental water and soil corrosion evaluation}

As shown in Table 3, due to the long-term immersion conditions or alternating wet and dry conditions, the $\mathrm{pH}$ of the site's environmental water is 7.16-7.19, the $\mathrm{Cl}^{-}$content is $20.9 \mathrm{mg} / \mathrm{L}$, and the total mineralization is
$557.82-575.6 \mathrm{mg} / \mathrm{L}$. The environmental water in the site area is slightly corrosive. The $\mathrm{pH}$ of the soil samples at the site is 8.67 , the $\mathrm{Cl}^{-}$content is $40.2-43.6 \mathrm{mg} / \mathrm{kg}$, and the total soluble salt is $499.1-1128.8 \mathrm{mg} / \mathrm{kg}$; thus, the soil samples at the site are slightly corrosive.

It is comprehensively inferred that the process of groundwater evaporation induced a considerable soluble salt migration phenomenon, especially for the geological environment of the sandy soil layer at the site. On one hand, the good permeability of the site soil will enhance the evaporation rate of groundwater and accelerated the speed of salt migration. On the other hand, the good

Table 1 List of statistics of standard penetration test results

\begin{tabular}{|c|c|c|c|c|c|c|c|}
\hline \multirow[t]{2}{*}{ Layer order } & \multirow[t]{2}{*}{ Layer name } & \multirow{2}{*}{$\begin{array}{l}\text { Number of } \\
\text { tests }\end{array}$} & \multicolumn{5}{|c|}{ Actual hammering number $\mathbf{N}$ (beat) } \\
\hline & & & Minimum value & $\begin{array}{l}\text { Maximum } \\
\text { value }\end{array}$ & Average value & $\begin{array}{l}\text { Standard } \\
\text { deviation }\end{array}$ & $\begin{array}{l}\text { Coefficient } \\
\text { of variation }\end{array}$ \\
\hline (1) & Fine sand & 4 & 16.0 & 27.0 & 20.5 & 5.4 & 0.27 \\
\hline (2) & Medium sand & 13 & 16.0 & 29.0 & 24.8 & 4.9 & 0.20 \\
\hline (3) & Gravel & 2 & 29.0 & 31.0 & 30.0 & 1.4 & 0.05 \\
\hline
\end{tabular}

Table 2 List of indoor penetration test results

\begin{tabular}{lcccccc}
\hline $\begin{array}{l}\text { Statistics items } \\
\text { Test items }\end{array}$ & Unit & Layer number & Maximum value & Minimum value & Average value & Evaluation \\
\hline Vertical permeability coefficient (Kv) & $\mathrm{cm} / \mathrm{s}$ & (1) & $5.44 \times 10^{-3}$ & $2.36 \times 10^{-3}$ & $3.67 \times 10^{-3}$ & Medium permeable \\
& & (2) & $5.77 \times 10^{-2}$ & $5.31 \times 10^{-3}$ & $1.31 \times 10^{-2}$ & Strongly permeable \\
& (3) & $1.73 \times 10^{-1}$ & $7.82 \times 10^{-3}$ & $8.98 \times 10^{-2}$ & Strongly permeable \\
& (4) & $6.76 \times 10^{-1}$ & $9.84 \times 10^{-2}$ & $3.66 \times 10^{-1}$ & Strongly permeable \\
& (5) & $3.48 \times 10^{-1}$ & $1.34 \times 10^{-5}$ & $1.16 \times 10^{-1}$ & Strongly permeable \\
& & & & &
\end{tabular}

Table 3 List of groundwater corrosion evaluation

\begin{tabular}{|c|c|c|c|c|c|c|}
\hline Aquifer & Corrosion evaluation & Environment type & Corrosive medium & Content & Limit value & Corrosion level \\
\hline \multirow[t]{10}{*}{$\begin{array}{l}\text { Pore diving groundwater } \\
\text { depth } 5.20-5.80 \mathrm{~m}\end{array}$} & \multirow{5}{*}{$\begin{array}{l}\text { Corrosion of water to } \\
\text { concrete structure } \\
\text { according to environ- } \\
\text { mental type }\end{array}$} & \multirow[t]{5}{*}{$\|$} & $\begin{array}{l}\text { Sulfate content } \mathrm{SO}_{4}{ }^{2-} \\
(\mathrm{mg} / \mathrm{L})\end{array}$ & $153.6-165.1$ & $<300$ & Micro \\
\hline & & & $\begin{array}{l}\text { Magnesium content } \\
\mathrm{Mg}^{2+}(\mathrm{mg} / \mathrm{L})\end{array}$ & $23.3-27.7$ & $<2000$ & Micro \\
\hline & & & $\begin{array}{l}\text { Ammonium content } \\
\mathrm{NH}_{4}^{+}(\mathrm{mg} / \mathrm{L})\end{array}$ & 0.2 & $<500$ & Micro \\
\hline & & & $\begin{array}{l}\text { Caustic content } \\
\mathrm{OH}^{-}(\mathrm{mg} / \mathrm{L})\end{array}$ & 0.0 & $<43,000$ & Micro \\
\hline & & & Total salinity (mg/L) & $557.82-575.6$ & $<20,000$ & Micro \\
\hline & \multirow{3}{*}{$\begin{array}{l}\text { Corrosion of concrete } \\
\text { structure by perme- } \\
\text { able water }\end{array}$} & \multirow[t]{3}{*}{$A$} & $\mathrm{PH}$ value & $7.16-7.19$ & $>6.5$ & Micro \\
\hline & & & Aggressive $\mathrm{CO}_{2}(\mathrm{mg} / \mathrm{L})$ & 0.0 & $<15$ & Micro \\
\hline & & & $\mathrm{HCO}_{3}^{-}(\mathrm{mmol} / \mathrm{L})$ & $3.75-3.80$ & $>1.0$ & Micro \\
\hline & \multirow{2}{*}{$\begin{array}{l}\text { Corrosion to reinforce- } \\
\text { ment in reinforced } \\
\text { concrete structures }\end{array}$} & Long-term immersion & \multirow[t]{2}{*}{$\mathrm{Cl}^{-}$content (mg/L) } & \multirow[t]{2}{*}{20.9} & $<10,000$ & Micro \\
\hline & & Wet and dry alternation & & & $100-500$ & Micro \\
\hline
\end{tabular}


permeability of the site soil will accelerate the speed of salt migration, and will accelerated the corrosion for the building materials, the traditional reinforced concrete building materials compared with the wooden structure, indicted that the corrosion resistance of wooden structure is obviously worse. Therefore, it can be inferred that this geological environment of the wooden site is not conducive to its long-term preservation.

\section{Preservation state of the ancient wooden bridge piles}

The wooden bridge piles were buried in sand for nearly two thousand years, and after the excavation, nearly $1 / 3$ of the wooden bridge piles were exposed to the air, as shown in Fig. 6. The ruin was damaged by natural factors after excavation, and the temporary protective shed conditions were limited; therefore, the overall preservation condition of the site was poor. The main diseases of the exposed wooden bridge piles on the ground include decay, cracks, incomplete areas, microbial damages, crooked flashes, fractures, discolouration, pollution, man-made damages (fire), and salt-alkali corroded areas. A comprehensive assessment determined that the disease progression is mostly moderate and severe, and a small portion of the ruin is endangered; the underground parts are mainly saturated with decay, cracks, warping, microbial damage, etc.

Combined with the results of the preliminary engineering geological survey, the site was excavated and sampled in situ. It was found that the soil layer of the ruins is evenly distributed within $6 \mathrm{~m}$ downward, and

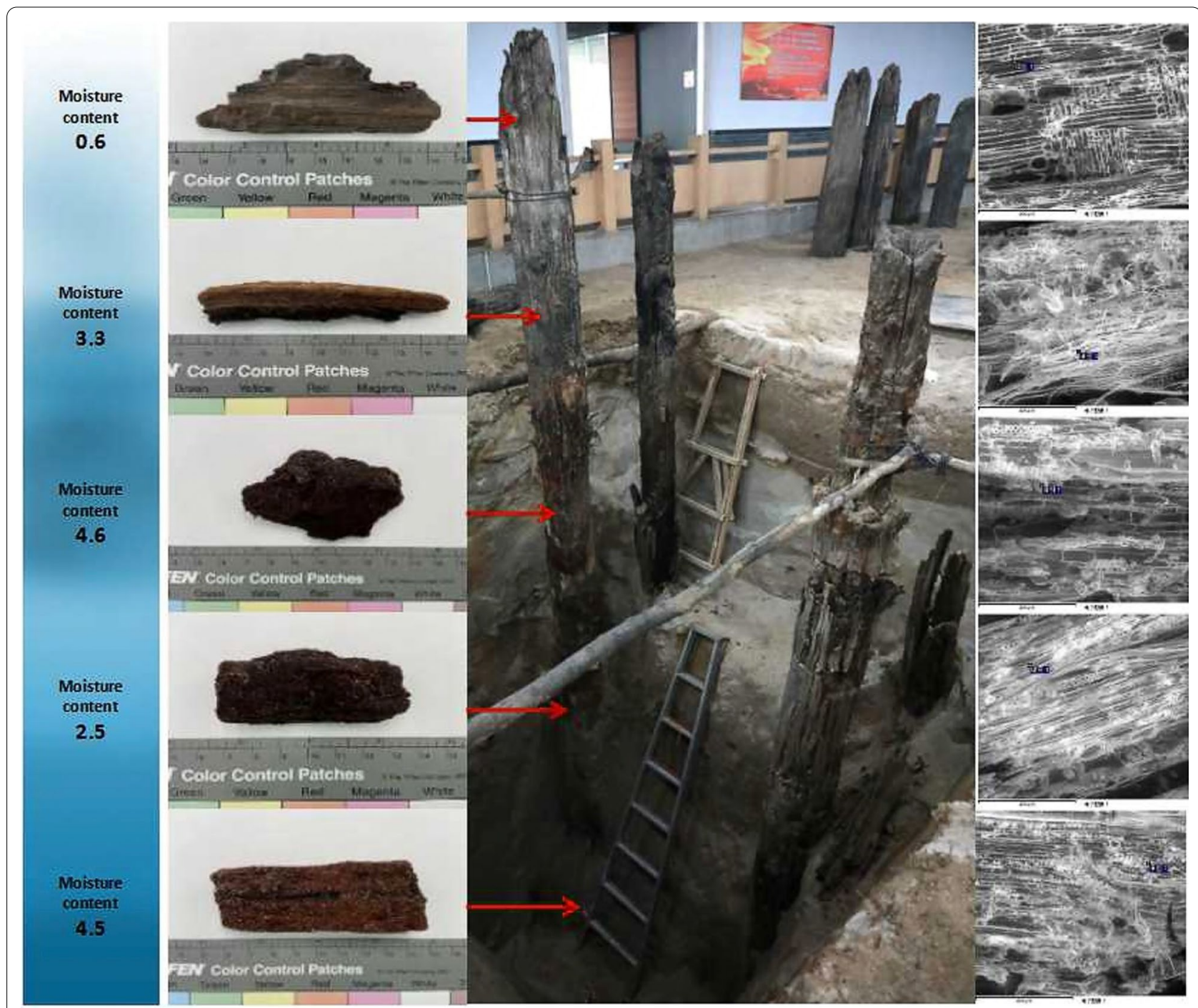

Fig. 6 Soil profile of the excavation site; moisture content of the soil (left 1), photographs (left 2) and microstructure (right) of wood samples with different burial depths 
the sand layer is well-graded with a high porosity that is conducive to water evaporation. The groundwater depth is $5.2 \mathrm{~m}$, and the capillary water zone is approximately $1.2 \mathrm{~m}$ high. As shown in Fig. 5, the ground was fully excavated down to the bottom of the wooden bridge piles; the depth of the wooden piles is $4.9 \mathrm{~m}$, and the volumetric water content of the sand in which the piles were located ranges from 0.6 to $4.5 \%$. Among them, the soil moisture content of the sand was significantly lower than that of the wooden piles, and the results confirmed that wooden bridge piles provided more convenient transport and water migration channels [33-35], further indicating that this damage was mainly caused by groundwater migration. On the other hand, the water content of the wooden bridge piles varied with the depth. The surface volumetric water content of the above-ground part was 3-8\%, making it dry, the underground part was mostly sub-saturated, and the surface volume water content was 8-29\% (tested during field excavation); the overall moisture content decreased as follows: pith $\rightarrow$ heartwood $\rightarrow$ sapwood.

The moisture content of the sites show a consistent decrease from bottom to top, especially at 1-2 m underground, where the water content is highest. We can infer that this pattern reflects the moisture content of the sand layer at the burial depth of the wooden piles. According to the experimental results regarding stratum permeability presented in Table 2 above, the soil layer at 1-2 $\mathrm{m}$ underground is medium sand, the permeability of which is greater than that of the fine sand near the surface; the near-surface permeability is comparatively poor. Furthermore, the capillary lifting distance of groundwater differs among the different soil layers. Compared with that near the surface, the water rises through capillary action more easily to the middle sand layer 1-2 $\mathrm{m}$ underground and accumulates there due to the reduced near-surface permeability, resulting in a higher water content. The moisture content of the near-surface layer is mainly compensated by the evaporation of the underground layer, which is affected by temperature and other factors; this evaporation makes it difficult for the near-surface layer to retain water, so it presents a low moisture content.

We found that the bottom of the wooden bridge is close to the groundwater depth, and the conduit structure of the log trunks is conducive to capillary water diffusion to the middle and upper parts of the wooden bridge pile. More importantly, the wooden piles at different burial depths have higher moisture contents than the soil. Therefore, it can be inferred that wooden capillaries are better channels for water transport and storage than is soil. The current preservation status of the wooden bridge piles verifies this inference. In addition, the water transport process provides a moist environment favourable for the growth of microorganisms, accelerating degradation.

\section{Wood species of the ancient wooden bridge piles}

After freezing, slicing, dyeing, dehydrating, and gluing, the wood samples were sealed with glass. Then, we observed, analysed and identified the cells of these wood species under a microscope. The anatomical characteristics of the wood samples are shown in Fig. 7. Machilus sp. has obvious growth rings, and it is diffused porous wood. The cross-section view shows that its tubes are round and oval-shaped. It has a single-tube hole and 2-3 radial-row multiple-tube holes. Tube holes are occasionally grouped with intrusions, as they have single perforation and sparse perforation ladder-like morphologies. The pits between the tubes are arranged in a polygonal shape. The axial parenchyma cells are small in number, ring-shaped, sparsely shaped such as a ring-tube bundle, and scattered, with a large number of oil cells or mucous cells. The wood fibres have thin walls and a large number of marginal holes. There are very few wood rays in a single row; multirow rays are $2-3$ cells wide, and most are $10-20$ cells high. It has type II and III ray tissue abnormalities, and there are few oil and mucous cells. The pitting type between the ray and the tube are either nicked and kidney-shaped, large round or tube-like pitting.

Larch sp. has obvious growth rings, and it is a diffused porous wood. The cross-section of the tube is round and oval shaped. It has a single-tube hole and $2-3$ radialrow multiple-tube holes. The tube holes are occasionally grouped with intrusions, including single perforation and sparse perforation ladder-like intrusions. The pits between the tubes are arranged in a polygonal shape. The axial parenchyma cells are small in number, ringshaped, sparsely shaped such as a ring-tube bundle, and scattered, with a large number of oil or mucous cells. The wood fibres have thin walls and a large number of marginal holes. There are very few wood rays in a single row; multirow rays are 2-3 cells wide, and most are 10-20 cells high. They have type II and III ray tissue abnormalities, and there are few oil and mucous cells. The pitting types between the ray and the tube consist of nicked and kidney-shaped, large round or tube-like pitting.

The identification results are as follows: the species of ancient bridge piles were identified as phoebe, fir, camphor, cypress, pine and other wood species, of which phoebe and larch constituted the majority. Both machilus and pine have a good corrosion resistance and a stable compression performance. The timber property information was obtained through the identification of wood species. Such information can be used to determine the timber conditions in the area at the time a site was 


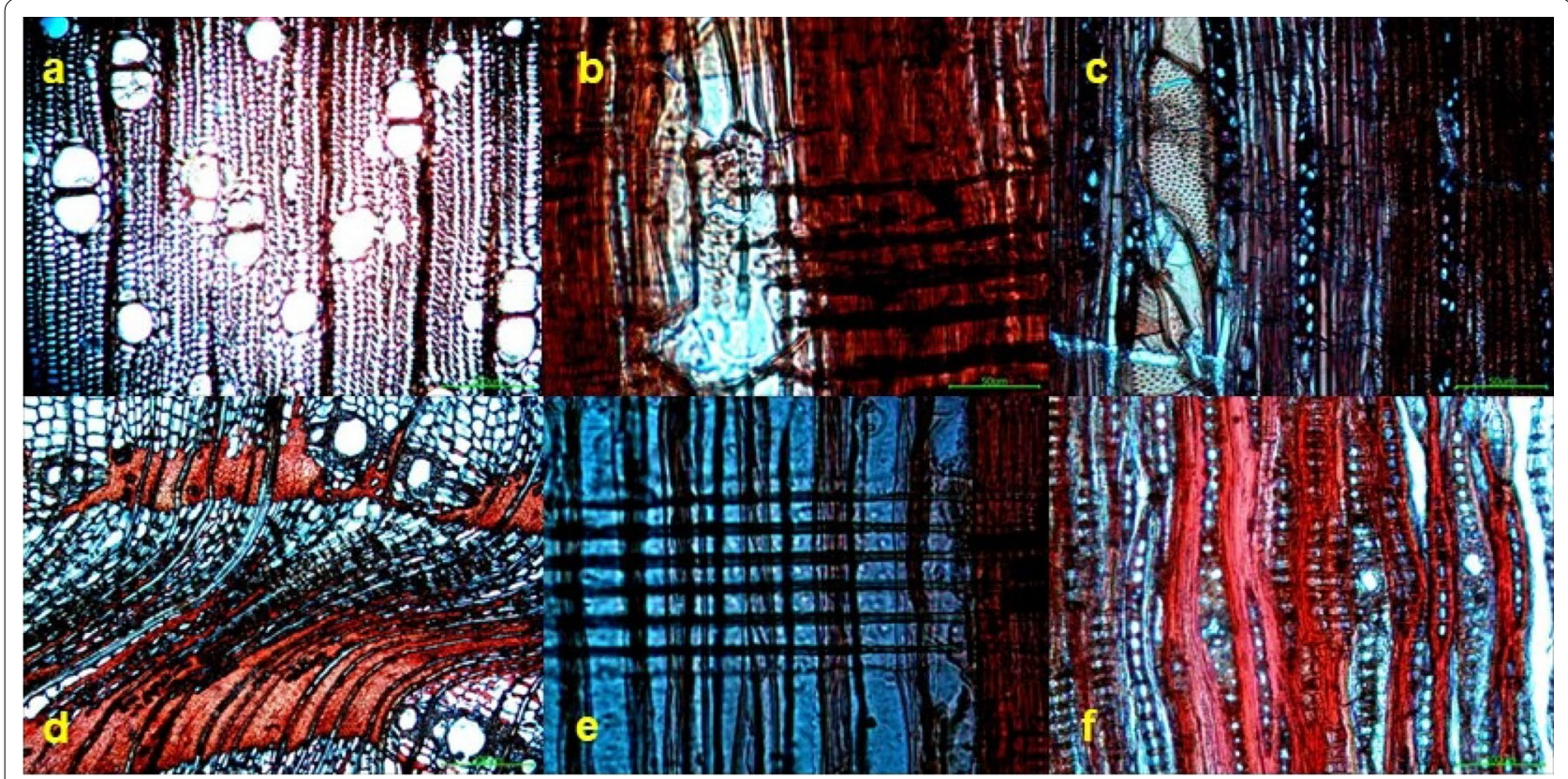

Fig. 7 The anatomical characteristics of machilus. a Cross section, $\mathbf{b}$ diameter section, $\mathbf{c}$ chord section and Larch sp. $\mathbf{d}$ cross section, e diameter section, $\mathbf{f}$ chord section

constructed. It also can provide a reference for the selection of wood protection materials and antiseptic reagents in the later stage and a basis for the selection of wood material replacement in restoration projects.

\section{Fungal isolation, identification and screening of ancient wooden bridge piles}

As shown in Fig. 8, the six samples collected were classified into 127 species, among which the microbial species richness of the samples in the ancient bridge pile area and soil contact was relatively high. According to the species classification, most samples were identified as follows: wood saprotroph, endophyte, ectomycorrhizal and animal endosymbiont. Ascomycetes had the highest content in the samples, followed by basidiomycetes. The wood presents fibrous and discrete pieces is found in Fig. 9a and $\mathrm{b}$ of the wooden pile material, the results showed that Ascomycetes had lignin degradation ability, suggesting that lignin can be decomposed not only by white rot fungi, but also by the fungi from the phylum Hemicycetes and Ascomycetes. Through the isolation and identification of microbial population composition, the characteristics of fungal population and whether there is diversity, as well as the association of specific changes in population structure with environmental changes at the site were obtained. Thus, the causes of microbial diseases can be inferred and targeted biological control strategies can be designed.

\section{Biological invasion of the ancient wooden bridge piles}

Since the site was under the simple preservation conditions provided by the temporary protective greenhouse, the seasonal and daily temperature and humidity changed greatly, thereby contributing to a growth environment that supports wood decay. Exposure to the ancient bridge piles caused the fungus to rapidly spread and grow. The groundwater environment accelerated the development of diseases. As shown in Fig. 9, the structure of the ancient wood pile is loose and has been seriously rotted, and residual organisms, microbial erosion, plant root tillering, organism parasite eggs, and organism excrement were observed in severely damaging capacities. The piles were penetrated by new plants and destroyed by their root system. At the same time, plants and their root systems were not found within a large area the soil surrounding the site, which indicates that the ancient bridge pile acted as a channel that was more conducive to groundwater evaporation, storage and transport, and the pile provided water for the epiphytic plants.

\section{Causes for deterioration}

The preservation status of the Shahe ancient bridge site is concerning. It is not difficult to see that the influence of the groundwater environment at the site cannot be ignored. On one hand, due to the climatic characteristics associated with groundwater evaporation at the site, the alternating dry and wet conditions and the soluble salt carried in the process of groundwater 

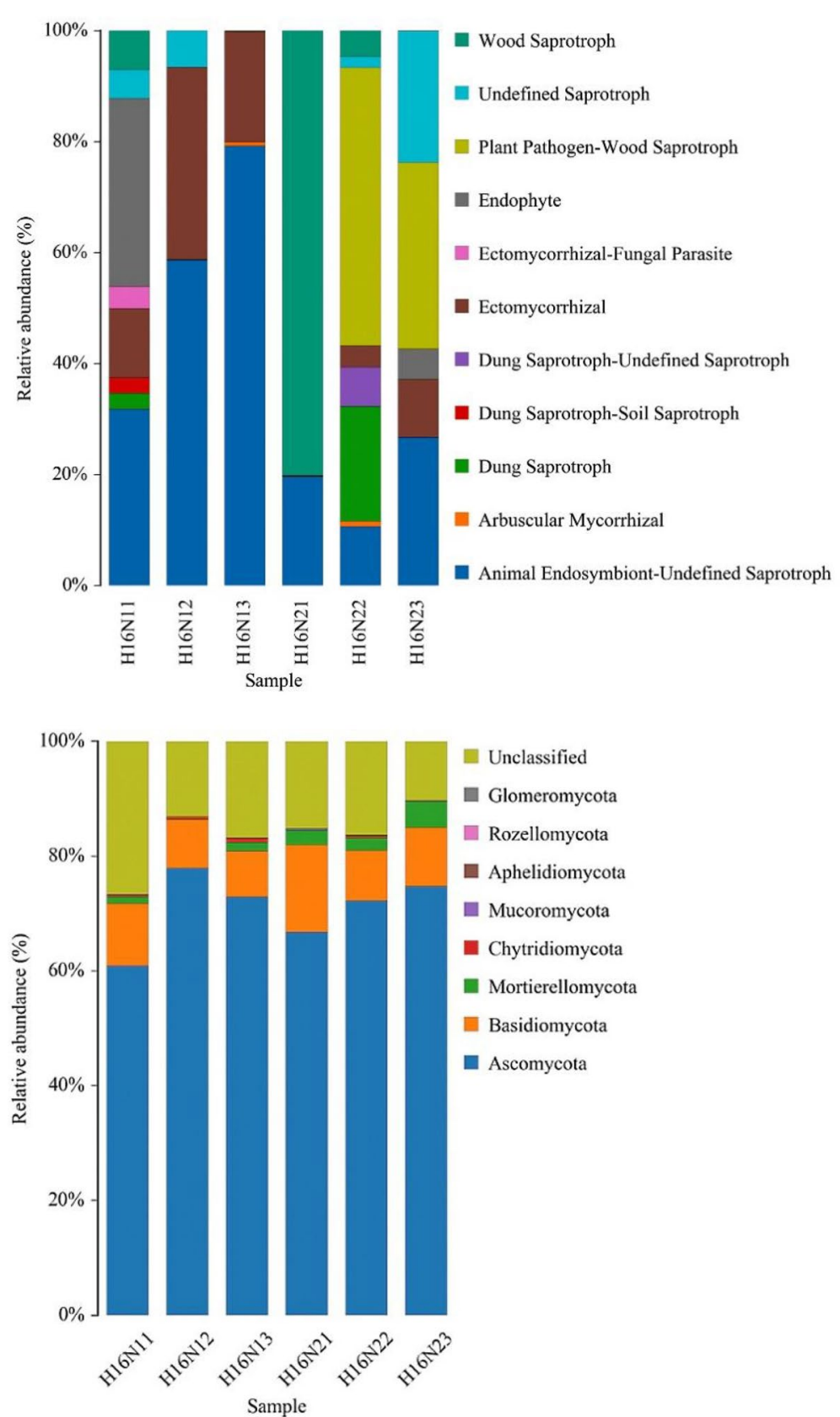

Fig. 8 Fungal abundance in different samples

evaporation have significantly accelerated the deterioration of the ancient site and its cultural relics. On the other hand, the erosion and destruction of the site caused by microorganisms, organisms, and plants that depend on water and humidity and the ecological environment around the site is also worthy of attention. If the groundwater environment is not treated as soon as possible and left unchecked, these wooden piles that have been preserved for thousands of years will eventually be destroyed by microorganisms, organisms, and plants. Therefore, groundwater management has become the primary problem facing the protection of ancient ruins. 


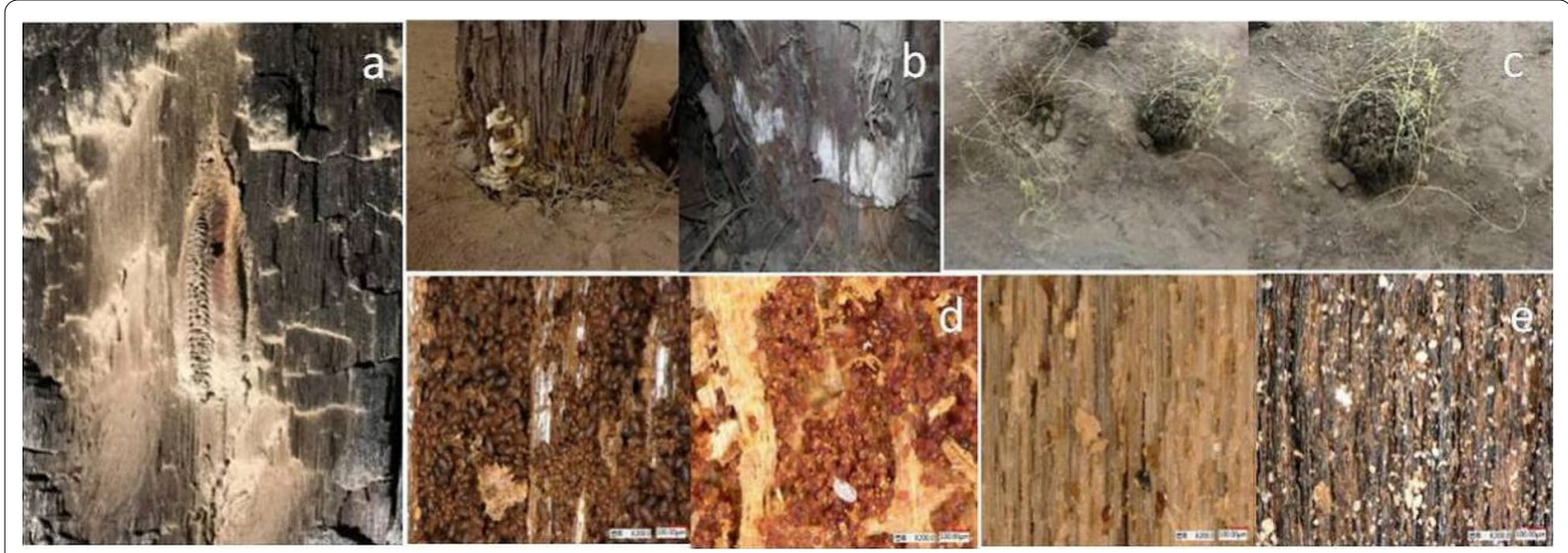

Fig. 9 Visual observations of microbial, biological, and plant erosion. a Residual organisms, b microbial erosion, c plant root tillering, $\mathbf{d}$ organism parasite eggs, and e organism excrement

\section{Conclusion}

With the improvement of the requirements and methods established for protecting ruins, we have found that ruins and their environment are absolutely and closely linked, and they are interdependent and interact with each other. How can we evaluate and understand the existence of these relationships? How can we analyse the various causes of disease progression and the conditions or factors that prompt it to continue to develop? How can we accurately evaluate its status and predict the speed and hazards associated with continuous development?

The diseases in ancient ruins are mostly influenced by geological, hydrological and environmental factors. Therefore, for the protection of cultural ruins, it is necessary to find a way to correlate the environment in which they exist to the causes of such diseases. At the same time, the aim is to partially or completely control the factors that cause site destruction or accelerate site degradation. A geotechnical investigation found that the hazards imposed on the Shahe ancient bridge site and its wooden bridge piles have been mainly caused by groundwater.

In general, the most important goal of site protection is to control or restrain a certain factor or several factors to stop or delay the destruction of sites caused by such factors; these influences were visible and effective within the short term in this study. However, from the perspective of self-regulating and rebalancing the site's ecosystem, "effective action at the moment" perhaps has disturbed the balance of the ecosystem and will continue to accelerate deterioration. In a practical sense, the effective management and protection of sites should balance various factors to establish a more stable balance, thereby gradually reducing the threat and finally realizing the long-term preservation and survival of precious cultural heritage artefacts. The author believes that the relationship between the environment and cause of deterioration at a site can be revealed by studying the correlations between the stratigraphy of the area, determined through geotechnical surveys, and both the preservation status of the site and the results of site sample analysis. In this paper, based on the investigation data and the preservation status of cultural relics, the influences of various damaging factors on long-term preservation and the associated mechanisms are predicted, and targeted management strategies and a long-term protection plan for damage control at the site are proposed.

This paper takes the Xianyang Shahe ancient wooden bridge site as the research object. This site located in the Fenghe River water system, and groundwater is the most important factor accelerating the destruction of the site. The bottom of the wooden bridge is close to the groundwater depth, and the conduit structure of the log trunks is conducive to capillary water diffusion to the middle and upper parts of the wooden bridge pile. More importantly, the wooden piles are better channels for water capillary transport and storage than the soil at the site. In addition, the water transport process provides a moist environment favourable for the growth of microorganisms and is accelerating degradation at the site.

This paper focuses on site degradation and presents suggestions and a long-term protection plan for damage control at the site:

(1) Monitor the groundwater level within a certain range at the site and the temperature and humidity of the underground wooden bridge piles and the soil to evaluate the influence of groundwater fluctuation on the degradation of pile materials. 
(2) Reduce the in situ depth of groundwater by drainage measures.

(3) In addition, groundwater migration usually occurs via the channel of least resistance the water vapour transport capacity of the surrounding area was increased, and the hygroscopic capacity of the pile was reduced by hydrophobic modification. As a result, the channel's transport capacity was altered such that the wooden posts were no longer the preferred passage, thus slowing the deterioration.

In summary, based on principles and previous studies, technologies and processes were successfully applied to the local experimental area of the Xianyang Shahe ancient wooden bridge site. Technical suggestions and details are proposed in this paper to provide guidance for the long-term protection of sites in China.

\begin{abstract}
Abbreviations
GPS: Global Positioning System; $\mathrm{f}_{\mathrm{s}}$ : Side friction resistance; $\mathrm{V}_{\mathrm{s}}$ : Shear wave velocity; $V_{p}$ : Compression wave velocity; $q_{c}:$ The cone tip resistance; $q_{s i k}$ : The standard value of the ultimate frictional resistance; $\mathrm{q}_{\mathrm{pk}}$ : The standard value of the ultimate resistance; CTAB: Hexadecyltrimethylammonium bromide; DNA: Deoxyribo Nucleic acid; PCR: Polymerase chain reaction; Q3: Quaternary 3.
\end{abstract}

\section{Supplementary Information}

The online version contains supplementary material available at https://doi. org/10.1186/s40494-021-00573-6.

Additional file 1. The characteristics of the rock and soil layer.

\section{Acknowledgements}

The authors would like to thank the Jingzhou Preservation Center of Cultural Relics and Shahe Ancient Bridge Site Cultural Relics Administration for their support and research cooperation and thanks the Tang Hanguang Gate Museum for sharing its monitoring data and experience with the ruins.

\section{Authors' contributions}

$J C$ conceived the research, designed the research methodology, performed experiments, data acquisition and processing, and drafted the manuscript. BM performed microbiological testing experiments and data acquisition and processing. $\mathrm{HC}$ designed the research methodology, discussed the results, and performed wood species identification and data acquisition and processing. YL discussed the results and reviewed and corrected the manuscript. JW designed the research methodology, conducted data analysis, and wrote the manuscript. All authors read and approved the final manuscript.

\section{Funding}

The authors gratefully acknowledge the financial support by the National Natural Science Foundation of China (No. 41601232) and the Fundamental Research Funds for the Central Universities (No. GK 20210361, GK 202103058). Also acknowledge the approval and financial support of the State Administration of Cultural Heritage for the Shahe Ancient Bridge Site Protection and Renovation Project (Cultural Relic Protection Letter [2018] 1135).

\section{Availability of data and materials}

The datasets used and/or analysis results obtained in the current study are available from the corresponding author on request.

\section{Declarations}

\section{Competing interests}

The authors declare no competing financial interests. We declare that we do not have any commercial or associative interest that represents a conflict of interest in connection with this work submitted.

\section{Author details}

${ }^{1}$ Engineering Research Center of Historical and Cultural Heritage Protection, Ministry of Education, Shaanxi Normal University, Xi'an 710069, Shaanxi, China. 2 Jingzhou Preservation Center of Cultural Relics, Jingzhou 434020, Hubei, China.

Received: 30 December 2020 Accepted: 10 August 2021

Published online: 23 August 2021

\section{References}

1. Casarin F, Modena C. Seismic assessment of complex historical buildings: application to Reggio Emilia Cathedral, Italy. Int J Archit Herit. 2008;2(3):304-27. https://doi.org/10.1080/15583050802063659.

2. Chellini G, Nardini L, Pucci B, Salvatore W, Tognaccini R. Evaluation of seismic vulnerability of Santa Maria del Mar in Barcelona by an integrated approach based on terrestrial laser scanner and finite element modelling. Int J Archit Herit. 2014;8(6):795-819. https://doi.org/10.1080/15583058. 2012.747115.

3. Berto L, Doria A, Faccio P, Saetta A, Talledo D. Vulnerability analysis of built cultural heritage: a multidisciplinary approach for studying the Palladio's Tempietto Barbaro. J Archit Herit. 2017;11(6):773-90. https://doi.org/10. 1080/15583058.2017.1290853.

4. De Matteis G, Mazzolani FM. The Fossanova Church: seismic vulnerability assessment by numeric and physical testing. Int J Archit Herit. 2010;4(3):222-45. https://doi.org/10.1080/15583050903078903.

5. Barbieri G, Valente M, Biolzi L, Togliani C, Fregonese L, Stanga G. An insight in the late Baroque architecture: an in tegrated approach for a unique Bibiena church. J Cult Herit. 2017;23(1):58-67. https://doi.org/10.1016/j. culher.2016.07.006.

6. Giannini R, Pagnoni T, Pinto PE, Vanzi I. Risk analysis of a medieval tower before and after strengthening. J Struct Saf. 1996;18(2):81-100. https:// doi.org/10.1016/0167-4730(96)00007-0.

7. Valentino B, Marco P, Alessandra M. Experimental cyclic and dynamic inplane rocking response of a masonry transverse arch typical of historical churches. J Eng Struct. 2017;147:285-96. https://doi.org/10.1016/j.engst ruct.2017.05.058.

8. Casolo S, Milani G, Alessandri C. Comparative seismic vulnerability analysis on ten masonry towers in the coastal Po Valley in Italy. J Eng Struct. 2013:49(1):465-90. https://doi.org/10.1016/j.engstruct.2012.11.033.

9. Pieraccini M, Dei D, Betti M, Bartoli G, Tucci G, Guardini N. Dynamic identification of historic masonry towers through an expeditious and no-contact approach: application to the 'Torre del Mangia'in Siena (Italy). J Cult Herit. 2014;15(3):275-82. https://doi.org/10.1016/j.engstruct.2017. 05.058.

10. Fortunato G, Funari MF, Lonetti P. Survey and seismic vulnerability assessment of the Baptistery of San Giovanni in Tumba (Italy). J Cult Herit. 2017;26(1):64-78. https://doi.org/10.1016/j.culher.2017.01.010.

11. Bosiljkov V, Uranjek M, Zarni R, Bokan-Bosiljkov V. An integrated diagnostic approach for the assessment of historic masonry structures. J Cult Herit. 2010;11(3):239-49. https://doi.org/10.1016/j.culher.2009.11.007.

12. Greif V, VIcko J. Key block theory application for rock slope stability analysis in the foundations of medieval castles in Slovakia. J Cult Herit. 2013;14(4):359-64. https://doi.org/10.1016/j.culher.2012.09.001.

13. Aguilar R, Marques R, Sovero K, Martel C, Trujillano F, Boroschek R. Investigations on the structural behaviour of archaeological heritage in Peru: from survey to seismic assessment. J Eng Struct. 2015;95(1):94-111. https://doi.org/10.1016/j.engstruct.2015.03.058.

14. Hemeda S, Pitilakis K. Geophysical investigations at Cairo's oldest, the Church of Abu Serga (St. Sergius), Cairo, Egypt. J Res Nondestruct Eval. 2017;28(3):123-49. https://doi.org/10.1080/09349847.2016.1143991. 
15. Hemeda S. 3D finite element coupled analysis model for geotechnical and complex structural problems of historic masonry structures: conservation of Abu Serga church, Cairo. Egypt J Herit Sci. 2019;7(1):6. https:// doi.org/10.1186/s40494-019-0248-z.

16. Hemeda S. Geo-environmental monitoring and 3D finite elements stability analysis for site investigation of underground monuments Horemheb tomb (KV57), Luxor, Egypt. J Herit Sci. 2021;9(1):17. https://doi.org/10. 1186/s40494-021-00487-3.

17. Falk KW, Gerhare DL, Bernd HK. Modeling of damage evolution in softwood perpendicular to grain by means of a discrete element approach. J Comput Mater Sci. 2005;32:594-603. https://doi.org/10.1016/j.comma tsci.2004.09.004.

18. Christensen M, Kutzke H, Hansen FK. New materials used for the consolidation of archaeological wood-past attempts, present struggles, and future requirements. J Cult Herit. 2012;13(3):183-90. https://doi.org/10. 1016/j.culher.2012.02.013.

19. Beckett CTS, Jaquin PA, Morel CJ. Weathering the storm: a framework to assess the resistance of earthen structures to water damage. J Constr Build Mater. 2020. https://doi.org/10.1016/j.conbuildmat.2020.118098.

20. Weikun W. A discussion about the newly found Shahe ancient bridge. J Northwest Univ. 2000. https://doi.org/10.16152/j.cnki.xdxbsk.2000.03.024.

21. Qinglin G, Xudong W, Zuixiong L, Lu Z. Condition survey and conservation of Dunhuang Yangguan Pass Beacon. 2007; 5 (105). https://doi.org/ 10.13584/j.cnki.issn1000-4106.2007.05.004

22. Cui K, Du Y, Zhang Y. An evaluation system for the development of scaling off at earthen sites in arid areas in NW China. J Herit Sci. 2019. https://doi. org/10.1186/s40494-019-0256-z.

23. State Administration of Cultural Heritage, Specifications of investigation for preservation engineering of earthen sites WW/T0040-2012. Standard. Beijing: Cultural Relics Press. https://www.antpedia.com/standard/13379 90819.html

24. Jing C, Yuhu L, Pinghua W. Identification of the Wood Species of the ancient buildings in Zhaojia Temple of Qinghai. J Northwest For Univ. 2019;34(4):236-8. https://doi.org/10.3969/j.issn.1001-7461.2019.04.36.

25. Yihang Z, Kai W, Li G, Hao W, Dongbo H. Species identification of archaeological wood used in the tomb of Marquis of Haihun, 2019; 31(05): 84-90. https://doi.org/10.16334/j.cnki.cn31-1652/k.2019.05.009
26. Felske A, Wolterink A, Van Lis R, Akkermans AD. Phylogeny of the main bacterial $16 \mathrm{~S}$ rRNA sequences in Drentse A grassland soils. J Appl Environ Microbiol. 1998;64(3):871-9.

27. Sterflinger K, Piñar G. Microbial deterioration of cultural heritage and works of arttilting at windmills. J Appl Microbiol Biotechnol. 2013;97(22):9637-46. https://doi.org/10.1007/s00253-013-5283-1 (Epub 2013; Oct; 8).

28. Gadd GM, Dyer TD. Bioprotection of the built environment and cultural heritage. J Microb Biotechnol. 2017;10(5):1152-6. https://doi.org/10.1111/ 1751-7915.12750 (Epub 2017; Jul;24).

29. Li Z, Wang X, Sun M, Chen W, Guo Q, Zhang H. Conservation of Jiaohe ancient earthen site in China. J Rock Mech Geotech Eng. 2011;3:270-81.

30. Shao M, Li L, Wang S, Wang E, Li Z. Deterioration mechanisms of building materials of Jiaohe ruins in China. J Cult Herit. 2013;14:38-44. https://doi. org/10.1016/j.culher.2012.03.006.

31. Du Y, Chen W, Cui K, Gong S, Pu T, Fu X. A model characterizing deterioration at earthen sites of the ming great wall in Qinghai Province, China. J Soil Mech Found Eng. 2017;53:426-34. https://doi.org/10.1007/ s11204-017-9423-y.

32. Huyuan Z, Ping L, Jinfang W, Xudong W. Generation and detachment of surface crust on ancient earthen architectures. J Rock Soil Mech. 2009;30:1883-91. https://doi.org/10.16285/j.rsm.2009.07.024.

33. Ping Z, Hao W, Hongjian Y, Baogang L, Haikun W. Research on influence of construction of soil layer on height of capillary water upward movement and evaporation of groundwater. J Water Saving Irrigation. 2011;3:6-8.

34. Ghanbarian B, Sahimi M, Daigle H. Modeling relative permeability of water in soil: application of effective-medium approximation and percolation theory. J Water Res. 2016. https://doi.org/10.1002/2015WR017903.

35. Russel C. The movement of water in soil columns and the theory of the control section. J Soil Sci Soc Am. 1947. https://doi.org/10.2136/SSSAJ 1947.036159950011000C0022X.

\section{Publisher's Note}

Springer Nature remains neutral with regard to jurisdictional claims in published maps and institutional affiliations.

\section{Submit your manuscript to a SpringerOpen ${ }^{\odot}$ journal and benefit from:}

- Convenient online submission

- Rigorous peer review

- Open access: articles freely available online

- High visibility within the field

- Retaining the copyright to your article

Submit your next manuscript at $\boldsymbol{\nabla}$ springeropen.com 